\title{
Mast cells and mast cell tryptase enhance migration of human lung fibroblasts through protease-activated receptor 2
}

\author{
Mariam Bagher ${ }^{1,2^{*}}$ D, Anna-Karin Larsson-Callerfelt', Oskar Rosmark', Oskar Hallgren², Leif Bjermer ${ }^{2}$ \\ and Gunilla Westergren-Thorsson ${ }^{1}$
}

\begin{abstract}
Background: Mast cells may activate fibroblasts and contribute to remodeling processes in the lung. However, the mechanism behind these actions needs to be further investigated. Fibroblasts are major regulators of ongoing remodeling processes. Protease activated receptor 2 (PAR2) expressed by fibroblasts may be activated by serine proteases, such as the mast cell mediator tryptase. The objective in this study was to investigate the effects of mast cells and specifically mast cell tryptase on fibroblast migration and the role of PAR2 activation.
\end{abstract}

Methods: Human lung fibroblasts (HFL-1) were cultured together with human peripheral blood-derived mast cells or LAD2 mast cells and stimulated with either conditioned medium from LAD2 cells or tryptase. Analyses of immunological stimulation of mast cells by lgE/anti IgE in the co-culture system were also performed. The importance of PAR2 activation by mast cells and mast cell tryptase for the migratory effects of fibroblasts was investigated by pre-treatment with the PAR2 antagonist P2pal-18S. The expression of PAR2 was analyzed on fibroblasts and mast cells.

Results: The migratory capacity of HFL-1 cells was enhanced by blood-derived mast cells $(p<0.02)$, LAD2 cells $(p<0.001)$, conditioned medium $(p<0.05)$ and tryptase $(p<0.006)$. P2pal-18S decreased the induced migration caused by mast cells $(p<0.001)$ and tryptase $(p<0.001)$ and the expression of PAR2 was verified in HFL-1 cells. Mast cells immunologically stimulated with IgE/Anti lgE had no further effects on fibroblast migration.

Conclusions: Mast cells and the mast cell mediator tryptase may have crucial roles in inducing lung fibroblast migration via PAR-2 activation, which may contribute to remodeling processes in chronic lung diseases.

Keywords: Human lung fibroblast, Lung, Mast cell, Migration, Protease activated receptor 2, Tryptase

\section{Background}

Mast cells $(\mathrm{MC})$ are involved in the innate immune response and play a major role in allergic diseases by releasing pro-inflammatory mediators such as histamine, prostaglandins and proteases such as tryptase and chymase [1]. During recent years, it has been suggested that mast cells may also have an important role in non-allergic chronic lung diseases, including chronic obstructive pulmonary

\footnotetext{
* Correspondence: Mariam.Bagher@med.lu.se

${ }^{1}$ Unit of Lung Biology, Department of Experimental Medical Sciences, Lund University, BMC C12, 22184 Lund, Sweden

2Department of Respiratory Medicine and Allergology, Skåne University Hospital, Lund University, Lund, Sweden
}

disease (COPD) [2], asthma [3] and idiopathic pulmonary fibrosis (IPF) [4, 5]. There are two major subtypes of human mast cells; mucosal mast cells with granules containing tryptase $\left(\mathrm{MC}_{\mathrm{T}}\right)$ and connective tissue mast cells with granules containing both chymase and tryptase $\left(\mathrm{MC}_{\mathrm{TC}}\right)$. Interestingly, the $\mathrm{MC}_{\mathrm{TC}}$ have been reported to increase at areas of inflammation and fibrosis [6]. Previous studies have shown increased numbers of mast cells in remodeled lung tissue, especially in fibrotic lesions [7] that correlated with the synthesis of type I collagen and other extracellular matrix (ECM) proteins [8]. Fibroblasts are mesenchymal cells that are crucial for maintaining ECM homeostasis in the lung $[1,9]$. Myofibroblasts have

(c) The Author(s). 2018 Open Access This article is distributed under the terms of the Creative Commons Attribution 4.0 International License (http://creativecommons.org/licenses/by/4.0/), which permits unrestricted use, distribution, and 
morphological features of both fibroblasts and smooth muscle cells. These cells are increased in number in chronic lung diseases and have been suggested to contribute to tissue remodeling processes [10]. Previous studies imply that mast cell mediators are involved in fibroblast differentiation into myofibroblasts [11]. Mast cell mediators, such as tryptase, may induce ECM synthesis, migration and proliferation in fibroblasts, resulting in airway remodeling. Mast cell tryptase has been suggested to be an important factor driving abnormal remodeling in chronic lung diseases by stimulating fibroblasts either directly, or by growth factor induction [12-14]. Previous studies suggest that mast cell tryptase may induce mitogenic activity in fibroblasts [13, 14], as well as increase the production of type I pro-collagen [8]. PAR2 is a G-protein coupled receptor activated by proteolytic cleavage by serine proteases, including tryptase [15]. The specific cleavage of the amino-terminus of PAR2 by tryptase, exposes a new amino-terminus, which interacts with another part of the cleaved receptor. This leads to the activation of downstream cell signaling pathways, involving binding to $\beta$-arrestins and activating ERK1, 2 [16]. PAR2 is expressed by several cell types and may be involved in tissue remodeling by inducing fibroblast migration, differentiation and ECM production $[17,18]$. The expression of PAR2 has been reported to be elevated in fibroblasts and myofibroblasts in IPF [19], as well as in inflammatory diseases [20]. Despite evidence that mast cells activate fibroblasts and contribute to remodeling, the mechanism for this interaction is poorly understood. For this reason, this study was designed to test the hypothesis that mast cells influence the migratory capacity of fibroblasts through PAR2.

\section{Methods}

Mast cells

Human peripheral blood derived mast cells (PBdMC) were generated by separating and isolating peripheral blood mononuclear cells. All blood donors gave their written informed consent to participate in the study, which was approved by the regional Ethics Committee in Lund (KIT 2010-29). The peripheral blood mononuclear cells were separated by Ficoll-plaque (Sigma Aldrich, St Louis, MO, US) [21] density gradient centrifugation and progenitor cells were separated using anti-CD34 magnetic beads with FcR blocking reagent (Miltenyi Biotec, Bergisch Gladbach, Germany). The progenitor cells were incubated $\left(5 \% \mathrm{CO}_{2}, 37^{\circ} \mathrm{C}\right)$ in StemPro ${ }^{\circ}$-34 Serum-free medium with Stem Pro-34 nutrient supplement (Invitrogen, Waltham, Massachusetts, USA), 1\% Penicillin-Streptomycin (PEST), 1\% L-glutamine (both from Gibco BRL, Paisley, UK), and the cytokines IL-3 (30 ng/ml, just first week), IL-6 (100 ng/ml, continuously from first week) and SCF
(100 ng/ml, continuously from first week) (Stem cell factor) (all from Peprotech, Stockholm, Sweden). The progenitor cells were incubated for 6 weeks in order to differentiate into mature mast cells (PBdMC), as a mix of both $\mathrm{MC}_{\mathrm{TC}}$ and $\mathrm{MC}_{\mathrm{T}}[22,23]$. The cell medium was changed by weekly hemidepletion. The mast cells were used within 10 weeks after the first day of isolation from peripheral blood [24-26]. The LAD2 mast cells (Dr. Arnold Kirshenbaum, Laboratory of Allergic Diseases, NIAID, Bethesda, US) were cultured in $500 \mathrm{~mL}$ StemPro 34 medium supplemented with $13 \mathrm{~mL}$ StemPro nutrients, $1 \%$ PEST, $1 \%$ glutamine and $100 \mathrm{ng} / \mathrm{ml} \mathrm{SCF}$. The cell concentration was doubled within 10 to 14 days and Stempro 34 medium mixture was added to the LAD2 cell culture by weekly hemidepletion, with a target cell density around $0.3-0.5 \times 10^{6} \mathrm{cells} / \mathrm{ml}$. A study described that LAD2 mast cells express both tryptase and chymase, however, in a lower concentration than primary skin mast cells [27].

\section{Characterization of peripheral blood derived mast cells (PBdMC)}

Transmission electron microscopy analysis

PBdMC were fixed with $4 \%$ formaldehyde and placed on 200-mesh, thin-bar copper grids. Uranyl acetate and lead citrate were added to stain the grids for imaging with transmission electron microscopy (CM-10 TEM microscope, Philips, Eindhoven, Netherlands) [28].

\section{Fluorescence-activated cell sorting (FACS) of PBdMC}

Differentiated PBdMC were harvested, washed and non-specific binding was blocked. The cells were stained with the following fluorophore conjugated antibodies: CD34 (cat.no 555824), CD117 (cat.no 550412), CD88 (cat.no 550494, all from BD Biosciences Pharmingen, Franklin Lakes, NJ, USA). 7-amino-actinomycin D (Sigma Aldrich, St Louis, MO, US) was used for excluding dead cells. Samples were acquired on a FACSCalibur $^{\text {rn }}$ cell analyzer and analysis was performed using the CellQuest software (both from BD Bioscience). Results are presented as per cent positively stained cells as compared to isotype controls.

\section{Immunocytochemistry staining of mast cells and human lung fibroblasts}

Human fetal lung fibroblasts (HFL-1; ATCC, Rockville, USA) were used between passages 17 and 20. HFL-1 (10000 cells/well) and co-cultures of HFL-1 $(10,000$ cells/well) and LAD2 cells (7500 cells/well), were seeded in 4-well glass chamber slides (154526; Thermo Scientific, Waltham, MA) and incubated overnight at $37{ }^{\circ} \mathrm{C}$, $5 \% \mathrm{CO}_{2}$. The cells were then fixed in $4 \%$ paraformaldehyde for 15 min and blocked in 2\% BSA-TBS containing $5 \%$ goat serum (Vector laboratories, Burlingame, CA) and $0.2 \%$ Triton-X for $30 \mathrm{~min}$, followed by washing 
twice in tris-buffered saline (TBS). Cells were incubated for 60 min with monoclonal tryptase antibody (M7052, Dako, Glostrup, Denmark) and monoclonal PAR2 antibody (cat.nr: 35-2300, Thermo Fisher Scientific, Waltham, Massachusetts, USA). The cells were then washed in TBS and incubated for 45 min with secondary antibodies (Thermo Fisher Scientific), goat anti-mouse IgG2a (Alexa Fluor 647, A21241), goat anti-mouse IgG1 (Alexa Fluor 647, A21240) or goat anti-mouse IgG1 (Alexa Fluor ${ }^{\circ} 555$, A21127), followed by washing in TBS. Nuclei were stained by using DAPI containing mounting medium (Dako). Cells were imaged using a VS120 slide scanner with XV image processor L100 VS-ASW (Olympus, Tokyo, Japan). Image viewer software VS-OlyVIA (version 2.9) (Olympus Soft Imaging solutions GmbH; Münster, Germany) was used for image visualization.

\section{Mast cell degranulation by $\beta$-hexosaminidase}

PBdMC and LAD2 cells were sensitized with IgE from human myeloma plasma $(100 \mathrm{ng} / \mathrm{mL}$, Calbiochem, Merck Chemicals, Beeston, Nottingham, UK) and incubated overnight in humidified $5 \% \mathrm{CO}_{2}, 37{ }^{\circ} \mathrm{C}$. After sensitization, the cells were degranulated by stimulation with anti-human IgE antibody $(0.5 \mu \mathrm{g} / \mathrm{mL}, \mathrm{KPL}$, Gaithersburg, MD, USA), and washed three times with HEPES buffer. The cells were resuspended in HEPES buffer and 5000-10 000 cells/well were plated in a 96-well plate. A calcium ionophore (A23187, Sigma Aldrich) was used as a positive control. The $\beta$-hexosaminidase assay was performed according to published protocol $[29,30]$. According to the protocol, mast cell degranulation by IgE/ Anti IgE occurs seconds after stimulation and reaches its peak after $25 \mathrm{~min}$. After that, the $\beta$-hexosaminidase release becomes constant. The time point $40 \mathrm{~min}$ was therefore chosen to assure that maximum degranulation and mediator release was obtained in the test system.

\section{Cell proliferation}

In vitro cell proliferation assays were performed as previously described [31, 32]. The HFL-1 cell cultures were grown in Dulbecco's Modified Eagle Medium (DMEM) culture medium (DMEM, Sigma-Aldrich, St Louis, MO) supplemented with $10 \%$ fetal clone serum (FCIII, Thermo Scientific, Waltham, MA), 1\% PEST and 1\% L-glutamine. HFL-1 $\quad(6,500 \quad$ cells/well; $200 \quad \mu \mathrm{l} /$ well $)$ respectively co-cultures $(200 \mu \mathrm{l} /$ well $)$ with HFL-1, (6,500 cells/well) and mast cells (LAD2, 5,000 cells/well) were seeded in 6 replicates in four 96-well plates. The cells were incubated for $6 \mathrm{~h}$ in $37{ }^{\circ} \mathrm{C}$ with $5 \% \mathrm{CO}_{2}$ in order to allow the cells to attach. Afterwards, the cells were washed with PBS, and new DMEM medium containing 10\% respectively $0.4 \%$ FCIII was added to the fibroblasts and the co-cultures in the presence or absence of mast cell tryptase $(75 \mathrm{ng} / \mathrm{ml}$, Sigma Aldrich). Conditioned medium from LAD2 cells was obtained in medium containing $10 \%$, respectively $0.4 \%$ FCIII serum $\left(0.1 \times 10^{6} \mathrm{cell} / 200 \mu \mathrm{l}\right)[31,32]$.

The cells in each plate were stimulated with the same treatment and allowed to grow up to $72 \mathrm{~h}$ after stimulation. After each time point, the medium was aspirated and cells were washed with PBS and fixed in glutaraldehyde. The cell density was optimized by using a cell nucleus staining solution, crystal violet $(0.1 \%)$ and incubated for $30 \mathrm{~min}$. After several washing steps in order to remove the unbound dye, the absorbed crystal violet in the cell nucleus was dissolved by adding Triton-X (1\%) and incubated over night at $4{ }^{\circ} \mathrm{C}$. The absorbance, at $600 \mathrm{~nm}$, was measured using a plate reader. The absorbance of the dissolved crystal violet is directly proportional to the cell density $[31,32]$.

\section{Cell migration}

A scratch assay was used to investigate cell migration in vitro [33, 34]. HFL-1 cells from passage 15-19, with a cell density of $0.13 \times 10^{6}$ cells/well $(2 \mathrm{~mL})$ were seeded in 6 -well plates. For the co-culture, $0.1 \times 10^{6}$ cells/well mast cells (PBdMC respectively LAD2) were re-suspended in DMEM medium (10\% FCIII), and mixed together with fibroblasts $\left(0.13 \times 10^{6} /\right.$ well $)$ and seeded in 6-well plates, $2 \mathrm{~mL} /$ well. The cells were incubated in $37{ }^{\circ} \mathrm{C}$ with $5 \%$ $\mathrm{CO}_{2}$ for $72 \mathrm{~h}$ to become confluent. After starvation for $24 \mathrm{~h}$ in medium containing $0.4 \%$ FCIII, the cell monolayer was scratched as a cross from one edge to the other in each well using a $1 \mathrm{ml}$ pipette tip. The cells were gently washed twice with PBS. DMEM with 0.4\% FCIII was added with and without different stimulating factors as described below, and incubated in $37{ }^{\circ} \mathrm{C}$ with $5 \% \mathrm{CO}_{2}$ for another $72 \mathrm{~h}$. Images of the scratch were captured at 0 , $24 \mathrm{~h}, 48 \mathrm{~h}$ and $72 \mathrm{~h}$ after the scratch using a TMS microscope (Nikon, Tokyo, Japan). The migratory capacity of HFL- 1 cells was measured at $24,48,72 \mathrm{~h}$ as the percentage of cell-occupied space compared to time $(0 \mathrm{~h}$, the starting point when the scratch was made). A scratch was created on a cell monolayer and the movements of the cells, the cell migration, was observed during different time points. Images of each scratch captured after $24 \mathrm{~h}$, $48 \mathrm{~h}$, and $72 \mathrm{~h}$ was compared to the image of itself at time point 0 , which was set as the reference point. A migration of $0 \%$ means the time point $0 \mathrm{~h}$, where the scratch was made and the cells had not started their migration, the area of this scratch is set as the reference point, while a $100 \%$ migration means that the scratch (cross) has reached total closure. The remaining cell free area was inversely correlated with the ability of the cells to migrate, the less empty cell free area in the scratch the more have the cells migrated. The scratch area was measured with the TScratch software [34, 35], the central dot was used as reference point to locate where photos were taken. In order to perform experiments without being limited by 
PBdMC amounts, LAD2 cells were used in the following experiments.

\section{Stimulation with mast cell tryptase}

Fibroblasts in monoculture were stimulated with three different concentrations of mast cell tryptase $(10 \mathrm{ng} / \mathrm{ml}$, $50 \mathrm{ng} / \mathrm{ml}$ and $75 \mathrm{ng} / \mathrm{ml})$.

\section{Stimulation with IgE degranulated mast cells}

The cells were sensitized by adding human IgE (100 ng/ml) at the same day as the starvation and then incubated overnight. Then human Anti IgE $(0.5 \mu \mathrm{g} / \mathrm{ml})$ was added to IgE sensitized mast cells to study the effect of immunological stimulation on fibroblast migration.

\section{Stimulation with conditioned media from LAD2 cells and IgE degranulated $L A D 2$ cells}

The IgE sensitized and the non-sensitized LAD2 cells were resuspended in DMEM medium (0.4\% FCIII). A cell density of $0.1 \times 10^{6}$ cells/well $(2 \mathrm{ml})$ was used also for the conditioned medium. Human Anti $\operatorname{IgE}(0.5 \mu \mathrm{g} / \mathrm{ml})$ was added to the LAD2 cells with and without the $\operatorname{IgE}$ sensitization, and incubated for $1 \mathrm{~h}$ in $37^{\circ} \mathrm{C}$ with $5 \% \mathrm{CO}_{2}$. The cell-suspension was centrifuged and the cell supernatant was considered as the conditioned medium.

\section{Pharmacological interventions with PAR2 antagonist}

The pepducin lipopeptide PAR2 antagonist P2pal-18S (palmitate-RSSAMDENSE KKRKSAIK-NH2, GL Biochem, Shanghai, China) was used to investigate if PAR2 is involved in the pro-migratory effects. Fibroblasts were pre-treated with different concentrations $(1,10,100 \mu \mathrm{M})$ of P2pal-18S for $1 \mathrm{~h}$ before stimulation with mast cell tryptase or addition of mast cells in the migration experiments.

\section{Gene expression, analysis for proteins and ELISA}

For the gene expression analysis, HFL-1 and LAD2 cells were washed with PBS, and total RNA was isolated with RNeasy mini kit (Qiagen, GmBH, Hilden, Germany). The cell mRNA concentrations were measured using Nanodrop ND-100 (Nano Drop Technologies, Delaware, Maryland, USA). Superscript II (Invitrogen) was added for the reverse-transcription of mRNA, followed by adding the PAR2 and F2RL-1 primers to the cDNA. Afterwards, CYBR Green Master Mix (Thermo Scientific) was added and reverse transcription PCR was performed using a StepOnePlus Real Time PCR system (Applied Biosystems, Waltham, Massachusetts, USA). The housekeeping gene $18 \mathrm{~S}$ was used as reference gene and quantifications were performed according to the manufacturer's instructions. Four different time-points were investigated; $0 \mathrm{~h}, 24 \mathrm{~h}, 48 \mathrm{~h}$ and $72 \mathrm{~h}$, according to the cell migration studies. Cell medium and lysate from each well were collected and stored at $-20^{\circ} \mathrm{C}$ for further investigations. The release of tryptase into the medium was quantified by ELISA and performed according to the manufacturers' instructions (Tryptase/TPSAB1, B2 PicoKine ELISA Kit, Nordic Diagnostica, Billdal, Sweden).

\section{Data analysis, calculations and statistical methods}

Statistical analyses and graphs were generated using the GraphPad software (GraphPad Software Prism 7, La Jolla, USA). For two-group comparisons in Figs. 1, 2, 3, 4 and 5, Student's t-test were used. To investigate migration over time and in response to stimulations and inhibitors, linear mixed models were used in Fig. 6 and in Additional file 1: Figure S1. To investigate the effect of time and different cell types in the area of cell migration, linear mixed models were employed. These types of models were chosen in part to account for the repeated measurement nature of the experimental design and in part due to its ability to handle the unbalanced design, i.e. that the number of observations for each cell type differs within one experiment. In order to investigate whether cell migration was different among the different cell stimulations over time, an interaction term of cell stimulations and time was included in the mixed model analysis. If the interaction term was not significant, results from a model without the interaction term is presented. These data analyses were performed using SPSS version 22 (SPSS, Inc., Chicago IL). $p$-values of * $p<0.05$, $* p<0.01$ and $* * * p<0.001$ were considered as statistically significant.

\section{Results}

Characterization of peripherally blood derived mast cells Matured peripherally blood derived mast cells (PBdMC) were differentiated from isolated human blood progenitor cells. Different characterization methods were used to confirm the mast cell phenotype. PBdMC were positive for tryptase, which is the main mast cell protease released during degranulation [30] (Fig. 1a). Transmission electron microscopy (TEM) showed mature PBdMC containing secretory vesicles (granules) (Fig. 1b), characteristic for mast cells. Although, many of the granules were empty indicating that the cells probably had degranulated (Fig. 1b). The PBdMC were positive for CD117 (c-KIT). As expected, PBdMC were negative for the progenitor cell marker CD34, a marker that is gradually lost during the differentiation process $[26,36]$. The PBdMC were negative for $\mathrm{CD} 88$, a marker that can be expressed by some mast cells (Fig. 1c). The efficiency of mast cell degranulation was analyzed by $\beta$-hexosaminidase. Degranulation of mast cells occurred after IgE/Anti IgE stimulation, where $0.5 \mu \mathrm{g} / \mathrm{ml}(p<0.004)$ was the most potent concentration, confirming the immunological 

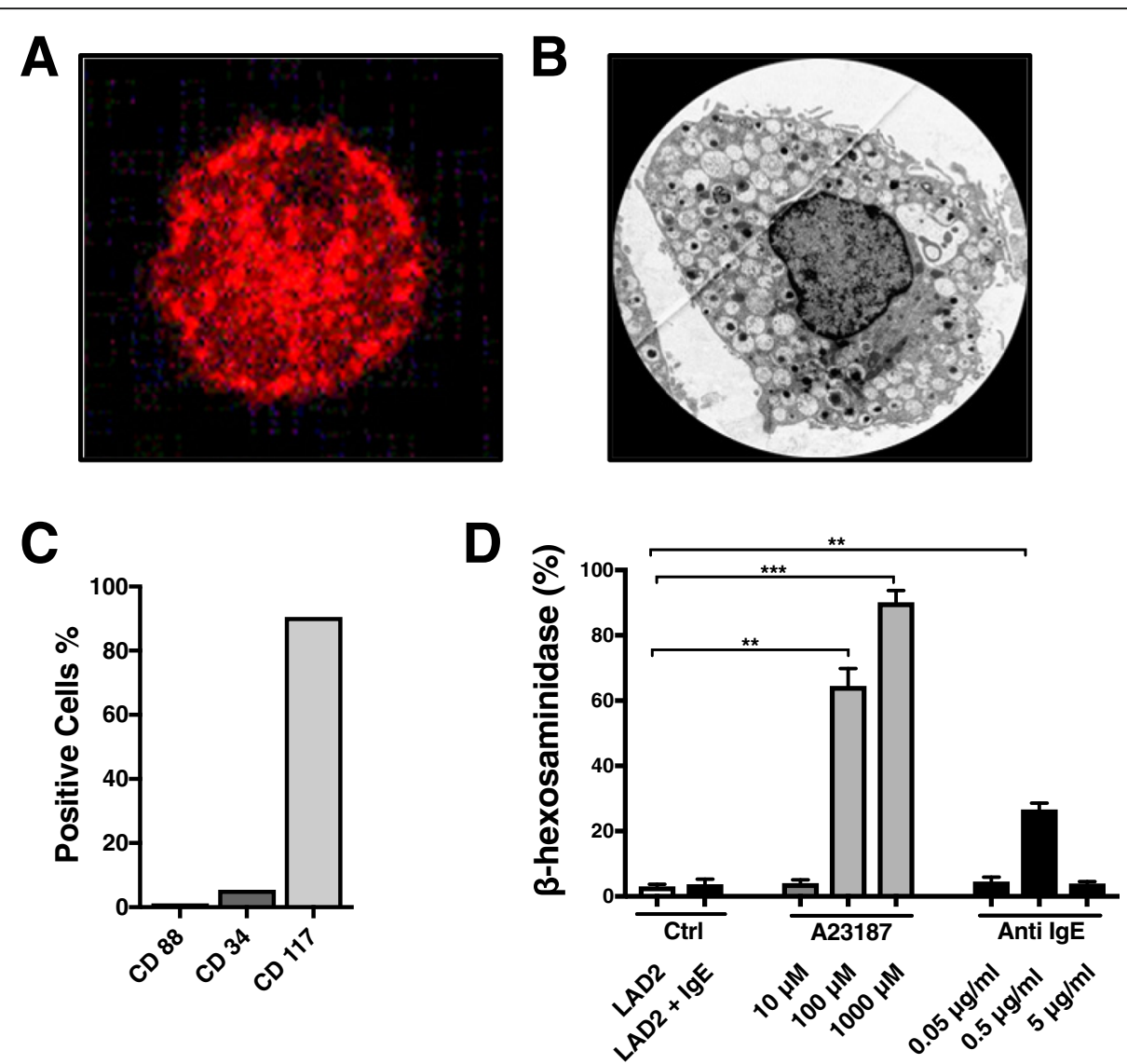

Fig. 1 Characterization of peripheral blood-derived mast cells (PBdMC) and LAD2 cells. Immunofluorescence staining for tryptase in mast cells, representative staining is shown in red for tryptase (a). Transmission electron microscopy image of a mature PBdMC (b). Flow cytometry of PBdMC using antibodies against CD117: Mast cell marker (C-Kit), CD34: Progenitor cell marker, CD88: Marker for some mast cells (c5a-receptor) (c). Mast cell degranulation was measured by the ability to release $\beta$-hexosaminidase. The calcium ionophore A23187 efficiently degranulated LAD2 cells in a concentration-dependent manner, IgE/Anti lgE stimulation also triggered degranulation of LAD2 cells but at a lower level than A23187 (d). The maximum effect was observed at 0.5 $\mu \mathrm{g} / \mathrm{ml}$ of Anti lgE. (mean \pm SD, 3 individual experiments with 3 technical replicates in each experiment, ${ }^{*} p<0.05,{ }^{* *} p<0.01$ and ${ }^{* * *} p<0.001$ )

degranulation being effective. The calcium ionophore A23187 was used as a positive control (Fig. 1d).

\section{Effects of mast cells on migration and proliferation of fibroblasts}

PBdMC significantly enhanced the migration of human lung fibroblasts compared to controls at both $48 \mathrm{~h}(p<$ $0.003)$ and $72 \mathrm{~h}(p<0.02)$ (Fig. 2a, e). PBdMC cells were stimulated with IgE/Anti IgE in order to examine the role of an induced immunological degranulation on fibroblast migration. Anti IgE stimulation reduced the migratory effect of PBdMC after $48 \mathrm{~h}(p<0.003$, Fig. 2a). Due to limitations in PBdMC amounts, LAD2 cells were instead used in the following experiments. Different cell concentrations of LAD2 cells showed a concentration-dependent effect on the migration of HFL-1, where the highest effect could be observed at $0.1 \times 10^{6}$ LAD2 cells/ $0.13 \times 10^{6}$ HFL-1 (Fig. 2b). LAD2 cells significantly enhanced the migration capacity of HFL-1 at $48 \mathrm{~h}(p<0.0001)$ and $72 \mathrm{~h}(p<$ 0.00005 ) (Fig. 2c, e), similarly to the effect of PBdMC. The pro-migratory effect on fibroblasts was however not affected by IgE/Anti IgE stimulation of the LAD2 cells (Fig. 2c). To investigate whether the observed effect of mast cells on fibroblasts also affected proliferation, we examined proliferation in medium containing $10 \%$ and $0.4 \%$ serum. The lower serum concentration $(0.4 \%)$ was the same as in the migration experiments, while the higher (10\%) was used as a positive control. In $10 \%$ serum, LAD2 decreased proliferation of HFL-1 at the time-points $48 \mathrm{~h}(p<0.013)$, and $72 \mathrm{~h} \quad(p<0.009)$, whereas there was no significant effect of mast cells on the proliferation rate of HFL-1 in $0.4 \%$ serum (Fig. $2 \mathrm{~d}$ ). Images of co-cultures with fibroblasts and mast cells clearly indicated a close cell-cell interaction between these cells in vitro; (Fig. 2f-h).

\section{Effect of conditioned medium on fibroblasts}

In order to examine the effects of soluble factors released by mast cells, conditioned medium (CM) from LAD2 mast cells was added to the fibroblasts and the 
A

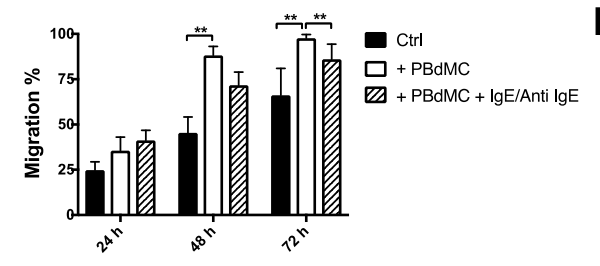

\section{C}

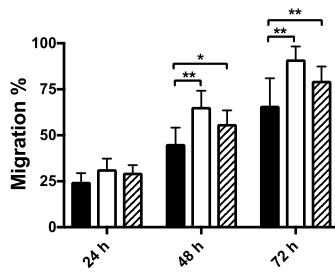

$\square^{\mathrm{Ctrl}}+\mathrm{LAD2}$

$\square+L A D 2+\lg E / A n t i \lg E$

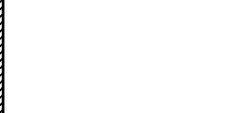

$B$

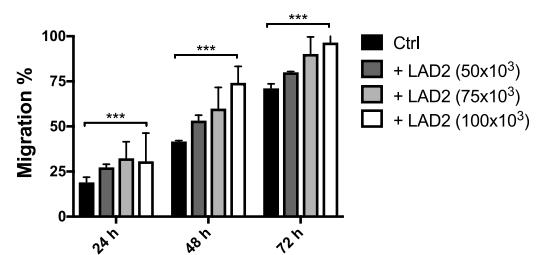

D

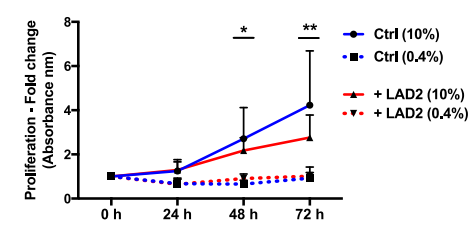

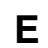
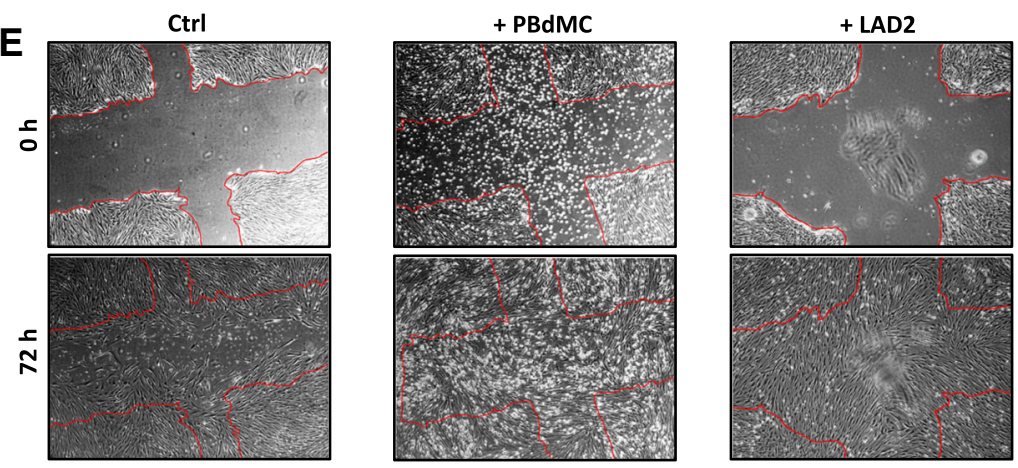

$\mathbf{F}$
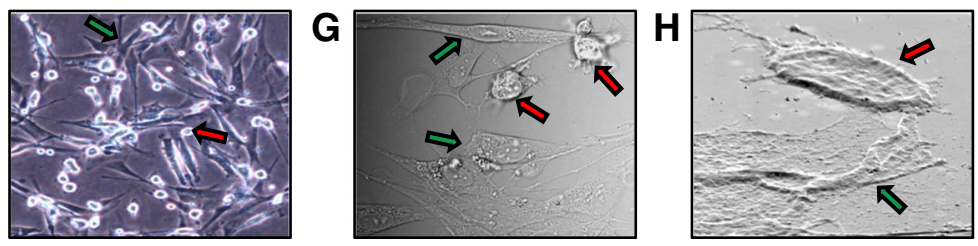

Fig. 2 Effect of mast cells on migratory capacity and proliferation of human lung fibroblasts, HFL-1. PBdMC enhanced the migratory capacity of HFL-1. Anti lgE stimulated PBdMC had a decreased pro-migratory effect compared to non-stimulated PBdMC (a). LAD2 cells, similarly to PBdMC, enhanced the migratory capacity of fibroblasts in a concentration-dependent manner, where the highest effect could be observed at $1 \times 10^{5}$ of LAD2 cells (b). There was no difference on the migration of HFL-1 in a co-culture with Anti IgE stimulated LAD2 compared to the non-stimulated LAD2 (c). The migratory capacity of HFL-1 cells was measured at 24, 48 and $72 \mathrm{~h}$ as the percentage of cell-occupied space compared to time $0 \mathrm{~h}$ when the scratch was made. LAD2 decreased proliferation of HFL-1 in co-cultures at 10\% serum concentration, and did not have any effect on proliferation of HFL-1 at $0.4 \%$ serum concentration (d). The proliferation of HFL-1 was measured at 24, $4872 \mathrm{~h}$. The cell growth was determined using time-point $0 \mathrm{~h}$ as the reference point. (mean $\pm \mathrm{SD}, n=3$ individual experiments with 4-6 technical replicates). Representative images of HFL-1 cells at $0 \mathrm{~h}$ (upper panels) and $72 \mathrm{~h}$ (lower panels). Images show $0.4 \%$ medium control, co-culture with PBdMC and co-culture with LAD2 (e) (mean $\pm S D, n=3$ individual experiments with 2 technical replicates in each experiment, ${ }^{*} p<0.05,{ }^{* *} p<0.01$ and ${ }^{* * *} p<0.001$ ). The image of co-culture with PBdMC at time point 0 h, show recently added mast cells floating in the cell medium before attached to HFL-1 (e). Light microscopy images of co-cultures of HFL-1 (green arrow) and PBdMC (red arrow) (f), confocal microscopy images of HFL-1 and LAD2 co-cultures (g), Scanning electron microscopy (SEM) images HFL-1 and LAD2 (h)

effect on migration was observed. CM enhanced the migratory capacity of HFL-1 cells at $72 \mathrm{~h}(p<0.05$, Fig. 3a, b). CM from IgE/Anti IgE stimulated LAD2 mast cells did not have a significantly different effect on fibroblast migration compared to $\mathrm{CM}$ from non-stimulated LAD2 cells (Fig. 3a).

Stimulation with $\mathrm{CM}$ had no significant effect on fibroblast proliferation, neither in $10 \%$ nor $0.4 \%$ serum concentrations (Fig. 3c).

\section{Effect of tryptase on migration and proliferation of fibroblasts}

Mast cells contain high concentrations of tryptase in their granules, which they release upon activation. Interestingly, we could observe a time dependent increase in concentrations of tryptase in our co-cultures. As expected, HFL-1 alone did not synthesize any tryptase. There was no significant difference in tryptase release from HFL-1 stimulated with conditioned medium 


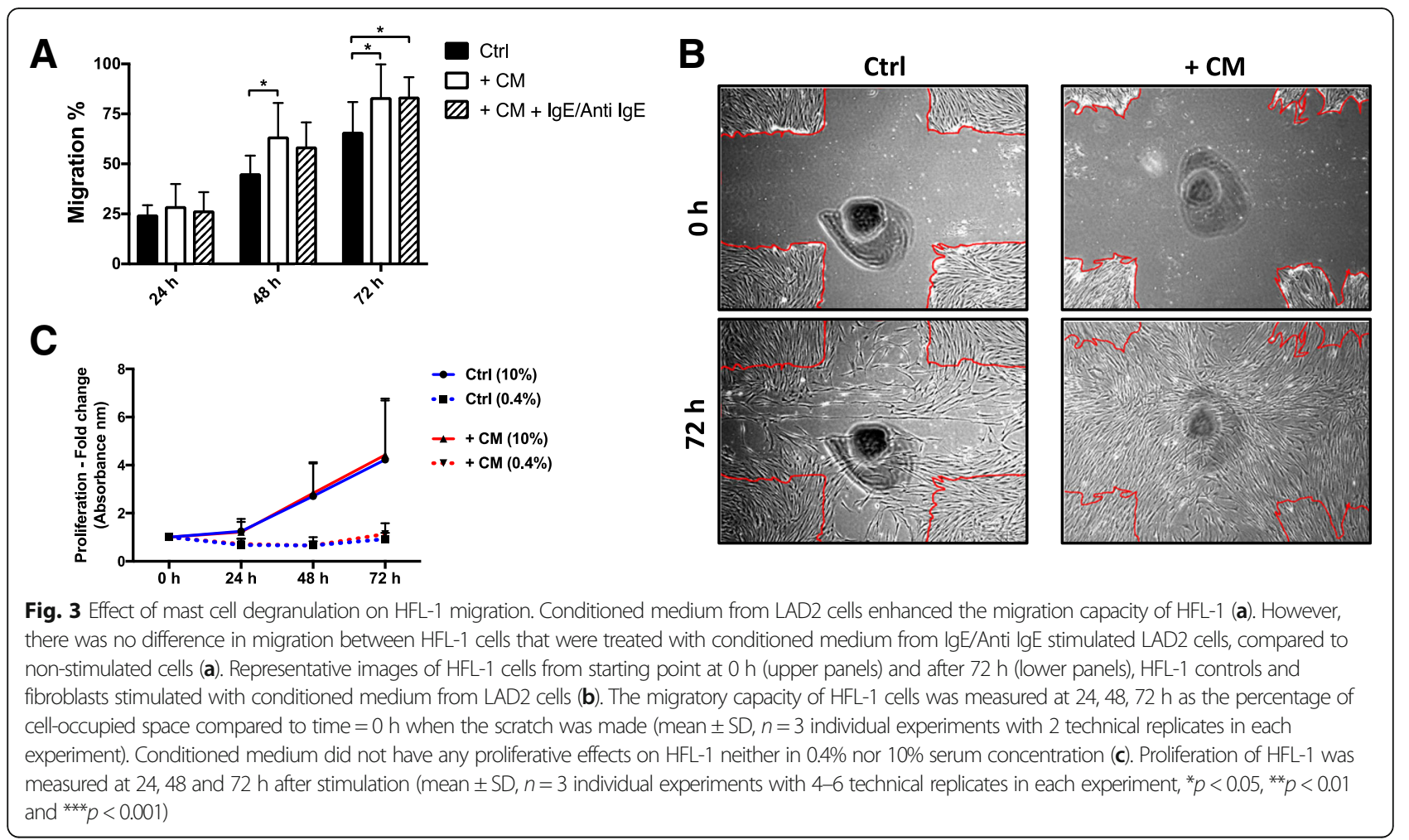

compared to HFL-1 alone (Fig. 4a). To study the effect of tryptase on fibroblast migration, different concentrations of tryptase $(10,50$ and $75 \mathrm{ng} / \mathrm{mL})$ were added to the HFL-1 cells [37-39]. The two highest concentrations (50 and $75 \mathrm{ng} / \mathrm{mL}$ ) of tryptase significantly enhanced the migration after $48 \mathrm{~h}(p<0.0009)$ and $72 \mathrm{~h}(p<0.006)$, compared to controls (Fig. $4 \mathrm{~b}, \mathrm{c})$. Tryptase showed a pro-proliferative effect on fibroblasts in medium containing $10 \%$ serum at time-point $48 \mathrm{~h}(p<$ 0.027 ), but had no significant effect on fibroblast proliferation in $0.4 \%$ serum (Fig. $4 \mathrm{~d}$ ). These experiments were also performed with another mast cell protease, chymase, which did not show any effects on either migration or proliferation (data not shown).

\section{Effect of PAR2 antagonist on fibroblast migration}

The PAR2 (F2RL1) gene was differentially expressed in a gene expression analysis, and was highly expressed in HFL-1, but not in LAD2 cells (Fig. 5a). Furthermore, the expression of PAR2 on HFL-1 both in monocultures and in co-culture with LAD2 was verified with immunocytochemistry (Fig. 5b-m). LAD2 cells did not express PAR2 (Fig. 5d). HFL-1 did not express tryptase (Fig. 5g), while LAD2 showed positive staining for tryptase (Fig. 5c). The PAR2 antagonist, P2pal-18S $(1 \mu \mathrm{M}$ and $10 \mu \mathrm{M})$, had no significant effect on migration of HFL-1 (Fig. 6a and Additional file 1: Figure S1A). Interestingly, P2pal-18S showed an inhibitory effect $(10 \mu \mathrm{M}, p<0.003,48 \mathrm{~h}$ and
$72 \mathrm{~h}$ ) on the pro-migratory effect induced by tryptase, compared to untreated controls (Fig. 6b). This could also be observed in the co-culture system where the enhanced migratory capacity of fibroblasts induced by LAD2 cells was inhibited by P2pal-18S $(10 \mu \mathrm{M}, p<0.001,48 \mathrm{~h}$ and 72 h, Fig. 6c; $1 \mu \mathrm{M}, p<0.05,48$ h, Additional file 1: Figure S1B). In contrast, migration of fibroblasts stimulated with conditioned medium was significantly enhanced in the presence of P2pal-18S (10 $\mu \mathrm{M}, p<0.005,48 \mathrm{~h} ; p<0.004$, $72 \mathrm{~h}$, Fig. 6d). In summary, LAD2 cells enhanced the migration of HFL-1 by $28 \%$ compared to untreated controls. This effect was decreased to $4 \%$ by the PAR2 antagonist P2pal-18S $(10 \mu \mathrm{M})$. Similarly, tryptase enhanced the HFL-1 migration by $21 \%$, while this effect was reduced to $0.015 \%$ by P2pal-18S (10 $\mu \mathrm{M})$ (Fig. 6e).

\section{Discussion}

We have demonstrated for the first time that mast cells (PBdMC and LAD2) and the mast cell mediator tryptase enhance the migratory capacity of human lung fibroblasts (HFL-1). Conditioned medium from LAD2 cells also increased the migration capacity of lung fibroblasts. These findings indicate that factors released by mast cells may trigger and enhance the migration of fibroblasts. This effect may be dependent on cell-cell contact, which in turn could be independent of immunologically activated mast cells. However, our data suggest that tryptase produced and released by mast cells, is one essential 


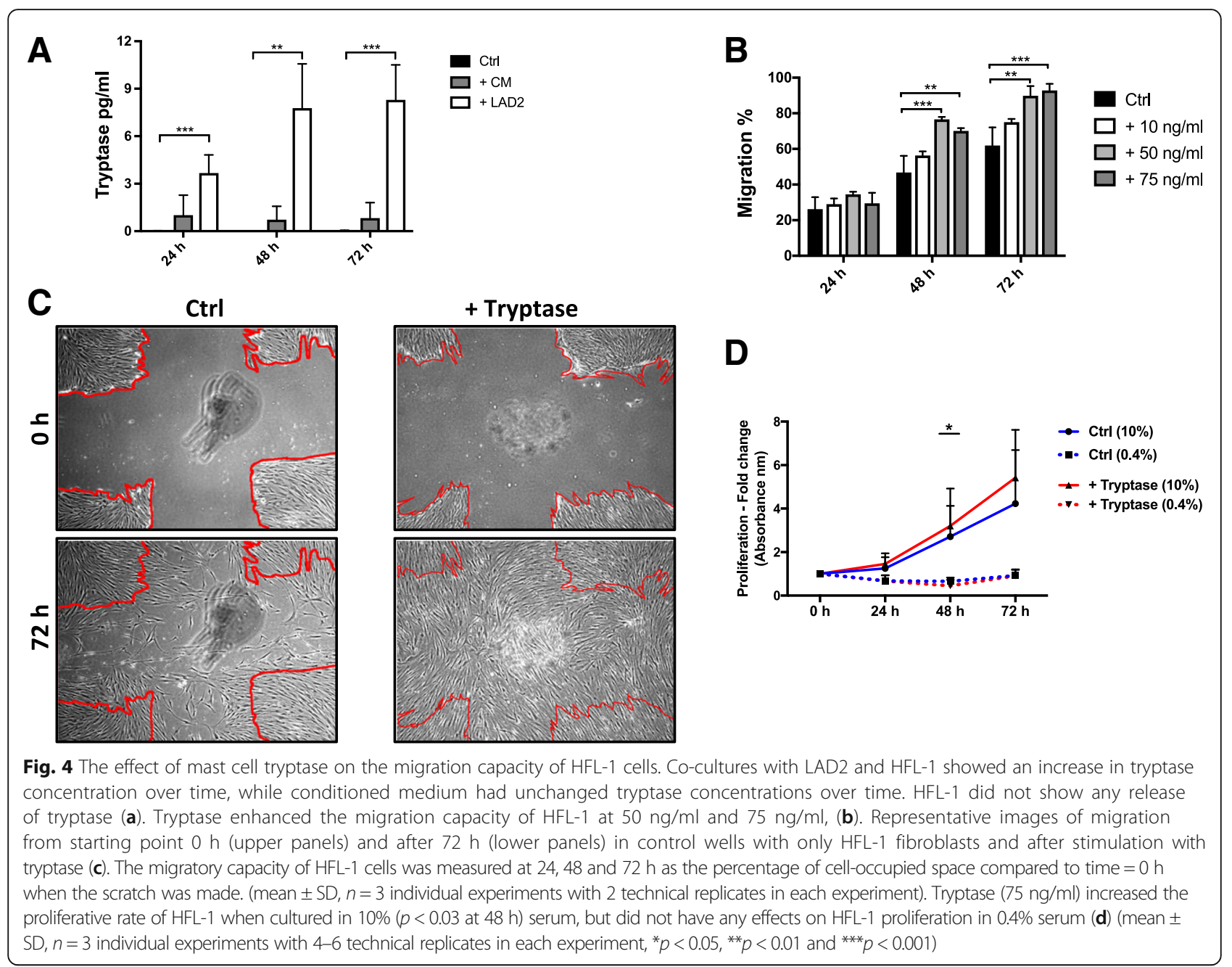

soluble factor causing the enhanced fibroblast migration. When inhibiting PAR2 on fibroblasts, we observed an almost complete inhibition of the pro-migratory effect of LAD2 cells and tryptase.

\section{Migratory and proliferative effects of mast cells on fibroblasts}

Several studies have reported that mast cell mediators and especially tryptase may have mitogenic effects on fibroblasts $[9,12]$. In the current study, we have showed that PBdMC enhanced the migration capacity of HFL-1 in a co-culture system. Similar results were observed when using the LAD2 mast cell line that induced migration of HFL-1 cells in a concentration dependent manner. The proliferation capacity of fibroblasts was investigated in the same low serum concentration as our migration experiments. As expected, we did not see any effect of mast cells in proliferation experiments with low serum, confirming that we were observing migration and not proliferation in our cell migration assays. However, mast cells significantly decreased fibroblast proliferation in high serum concentration, suggesting that mast cells may have an anti-proliferative effect on fibroblasts, which is serum-dependent. This effect could be a combination of different mast cell proteases acting together [40], higher amounts of protease inhibitors and growth factors or that mast cells may promote the synthesis of anti-fibrotic growth factors, potentially making mast cells protective against remodeling processes in the lung [41]. However, the mechanisms underlying these activities remain unclear.

In our experiments, we observed a concentration-dependent increase in fibroblast migration in response to tryptase. In view of published data on mitogenic properties of mast cell tryptase $[9,12]$, we speculated that the changes in migration could be due to an increased cell proliferation rate. However, we could not see any proliferative effect of tryptase on fibroblasts in the low serum concentration used in our migration experiments. In line with other studies $[9,12]$, tryptase in high serum concentration significantly increased fibroblast proliferation, 


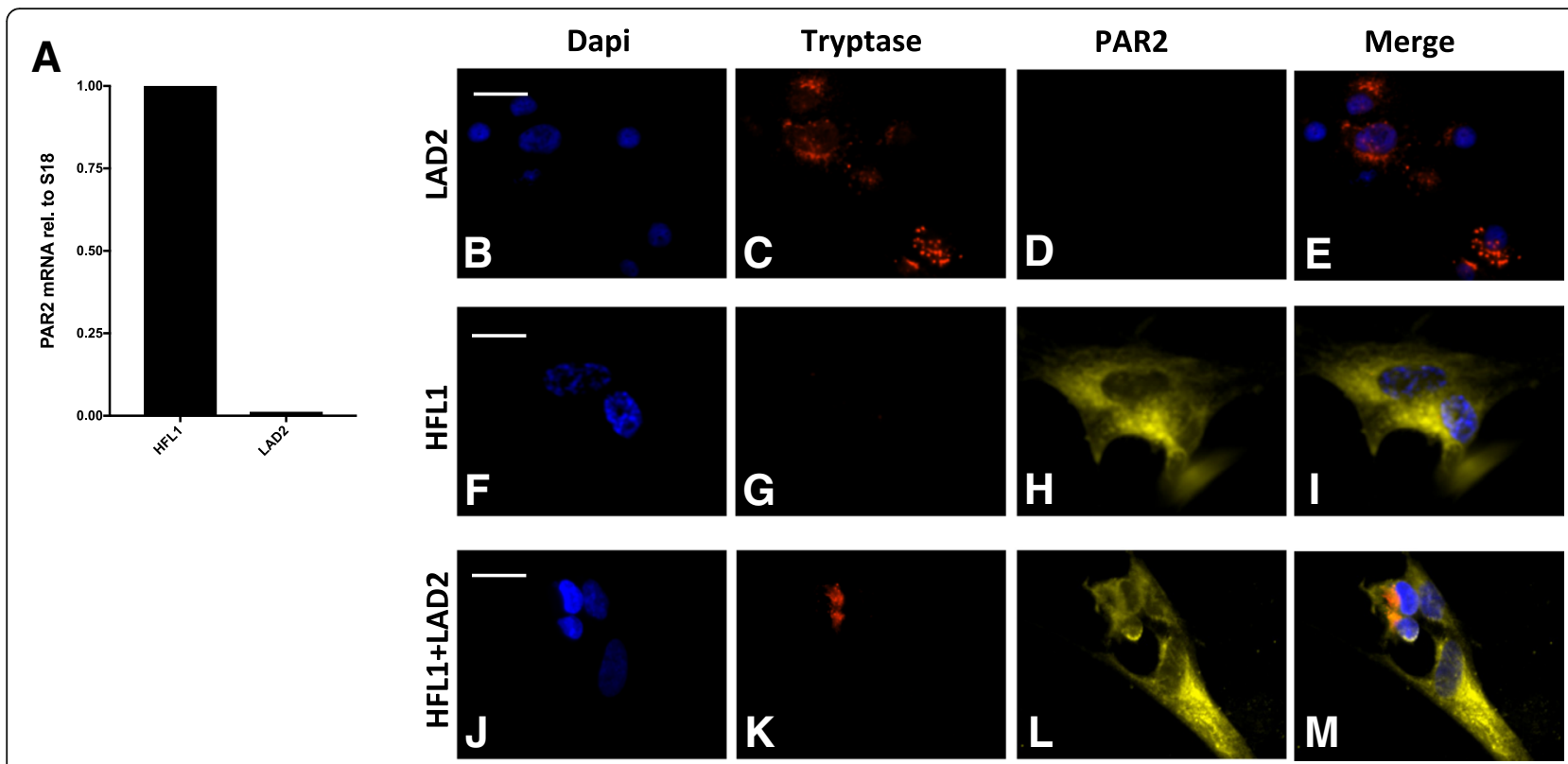

Fig. 5 Expression of PAR2 in HFL-1 cells. RTqPCR was used to confirm the expression of the serine protease receptor PAR2 on HFL-1. The relative gene expression was related to the housekeeping gene $18 \mathrm{~s}(n=2,1$ experiment). Human lung fibroblasts, HFL-1, showed a high gene expression for PAR2, while LAD2 cells did not show any PAR2 gene expression (a). Expression of PAR2 examined in monolayer cultures of HFL-1, LAD2, and in coculture of HFL-1 and LAD2. Representative images are shown with PAR2 staining in yellow, mast cell specific tryptase-staining in red and nuclei stained with DAPI in blue (b-m). LAD2 cells stained by PAR2 antibodies showed no positive receptor staining (d), while HFL-1 fibroblasts showed a positive expression (h). HFL-1 showed no positive staining for tryptase (g), while mast cells were immunopositive (c). Representative scale bars are shown at the beginning of each figure $(\mathbf{b}, \mathbf{f}, \mathbf{j})$ and indicated as $20 \mu \mathrm{m}$

suggesting that the interactions between mast cells and fibroblasts are serum-dependent. Thus, our contradictory results on fibroblast proliferation when comparing tryptase and co-cultures with mast cells in higher serum concentration, may be due to cell-cell interaction or other soluble factors released by mast cells.

\section{Secreted mast cell mediators and cell-cell interactions} In order to study whether the mediators involved in fibroblast-mast cell interactions were released in the cell medium or dependent on cell-cell contact, we investigated the effect of CM from mast cells on fibroblast migration. Interestingly, CM significantly enhanced fibroblast migration, however weaker. When investigating tryptase levels in co-cultures of fibroblasts and mast cells, we observed a time dependent increase in tryptase concentrations, while conditioned medium showed unchanged tryptase concentrations overtime.

In order to investigate whether mast cells release tryptase through an immunological response, mast cells were stimulated with IgE/Anti IgE [42]. However, IgE degranulation of $\mathrm{PBdMC}$ attenuated the pro-migratory effect on HFL-1. Importantly, we did not detect any differences between IgE-activated or non-activated LAD2 mast cells or conditioned medium from these cells. However, an explanation to this could be that PBdMC may express different amounts of IgE receptors compared to LAD2 [27]. Another reason for this might be the differences in mediator release between the two degranulation pathways in mast cells; i.e. the anaphylactic degranulation (immunological degranulation) and the piecemeal degranulation (PMD) [43, 44]. It has been suggested that chronic, low-grade partial activation of mast cells could have a role in the pathogenesis of pulmonary fibrosis [45]. Different factors have been proposed to trigger PMD in mast cells in a clinical setting, including chronic psychosocial stress, interactions with regulatory $\mathrm{T}$ cells or stimulations of CCL2 and TLR [44]. A selective release of mast cell mediators has been hypothesized to occur during PMD, where the morphology of the granules remains relatively unchanged [46]. However, the pathways behind these actions remain unknown. Dvorak et al., suggested that mast cells may release their granules via PMD in wound healing, and then refill their granule content during this process [44]. These results may explain our findings that IgE-stimulation on mast cells did not further increase fibroblast migration. One important mediator that may be involved in PMD and secreted by fibroblasts is the SCF. SCF is expressed both in the transmembrane and extracellularly by fibroblasts, and is considered to be the driving force in recruiting and activating mast cells towards injured and inflamed 


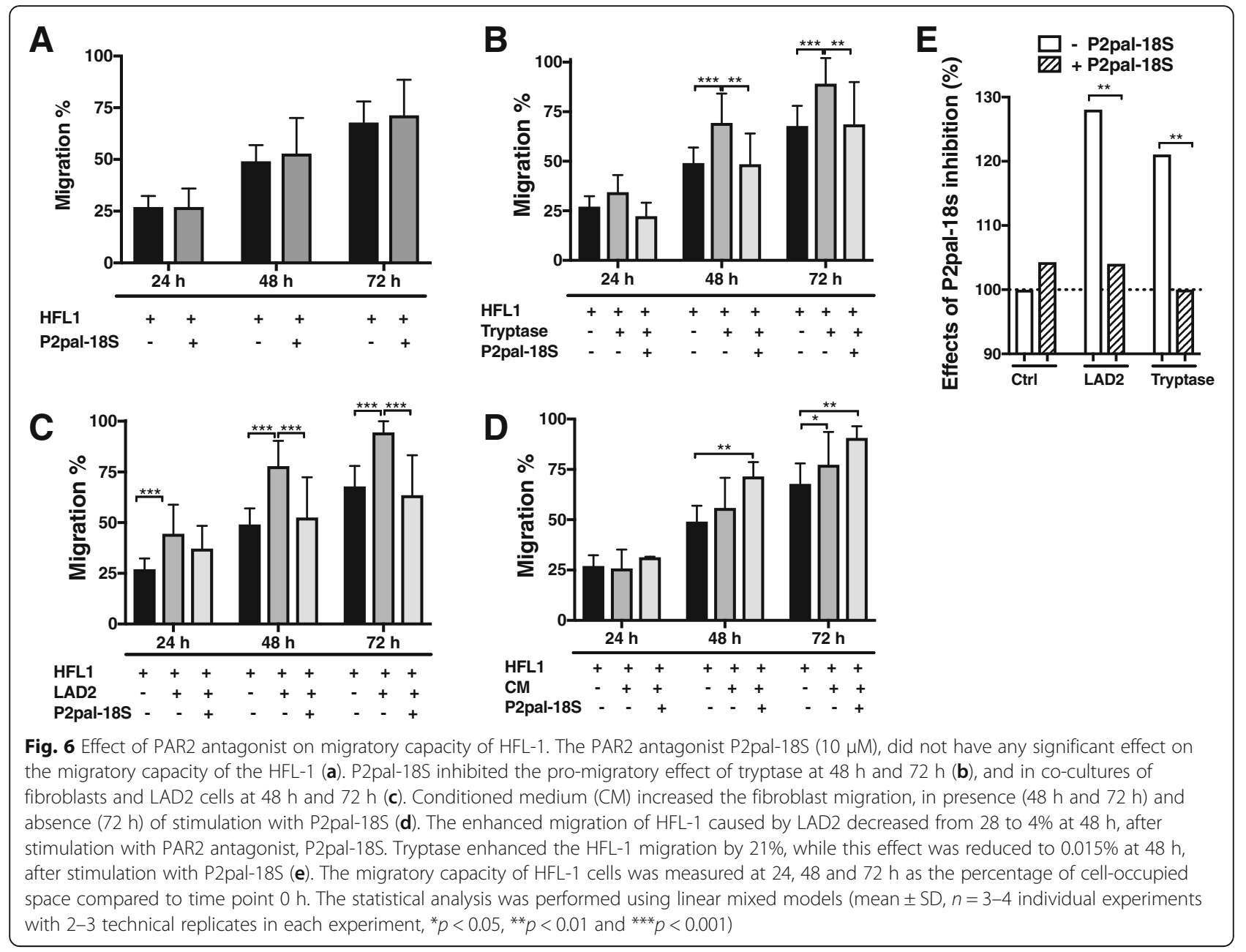

sites. SCF binds to C-KIT receptor expressed by mast cells. It is well known that SCF has a crucial role in mast cell development, proliferation and maturation, however several studies have also reported SCF as a mast cell activator inducing degranulation [47-49]. An interesting study reported that fibroblast-SCF interaction with c-KIT receptors on mast cells caused degranulation and activation of mast cells, resulting in synthesis of eotaxin $[47,50]$. Eotaxin is an eosinophil-specific chemoattractant, implicated to be dependent on the interactions between fibroblasts and mast cells, however both these cells may produce eotaxin [50]. Hogaboam et al. also showed that the production of SCF by pulmonary human fibroblasts, may be induced by tumor necrosis factor- $\alpha$, which is produced by mast cells $[50,51]$. Wygrecka et al. presented data showing elevated transmembrane SCF expression in fibroblasts from IPF lungs compared to control lungs [5].

However, further experiments are needed in order to clarify the mechanisms causing PMD [52], and to understand the role of mast cells in chronic lung diseases. Interestingly, we noticed some degranulated mast cells without IgE-stimulation using transmission electron microscopy, which could be explained by PMD activation.

In view of our findings and what others have reported about PMD, we propose an important role of cell-cell communication and signaling between mast cells and fibroblasts. We suggest that the interaction between these two cell types could trigger tryptase release through PMD. However, more studies are needed in order to conclude the molecular mechanisms involved in these signaling pathways.

\section{Role of PAR2 activation on fibroblast migration}

In our study we confirmed that HFL-1 expressed mRNA for PAR2, while LAD2 cells did not. Also immunocytochemical stainings confirmed the expression of PAR2s on fibroblasts and the lack of PAR2 on LAD2 cells. A peptide, P2pal-18S, has been reported as a promising antagonist for the PAR2 expressed by human pulmonary fibroblasts $[15,53]$. In the present study, the PAR2 antagonist P2pal-18S reduced mast cell-induced fibroblast migration. We could also observe an inhibition of the pro-migratory effect of tryptase, whereas the PAR2 
antagonist showed no significant effect on fibroblast migration induced by CM from LAD2 cells. These differences could be due to continuous degranulation of mast cells (PMD) in the co-cultures with mast cells and fibroblast, which did not occur during stimulation with $\mathrm{CM}$ alone. In CM there was a limited amount of mast cell components, especially tryptase as we showed in our results. However, in co-cultures mast cells could provide the factors needed for PAR2 activation.

Our results from the migration experiments when investigating the $\mathrm{CM}$ from IgE/Anti IgE stimulated mast cells, showed no differences compared to the non-stimulated mast cells. However, this could probably be explained by the limited amount of mast cell tryptase in CM. An explanation to the enhanced fibroblast migration both after stimulation with mast cells and CM could be that different factors are involved, acting through different pathways. In co-cultures, direct cell-cell interactions may be important in addition to soluble factors, including tryptase, present in CM. Cong Lin et al., have demonstrated that PAR2 inhibition by the peptide P2pal-18S reduced pro-fibrotic and pro-inflammatory responses caused by PAR2 activation [15]. Another study has reported that PAR2 activation induced pulmonary fibroblast migration, differentiation and ECM production. This activation occurred by trypsin as a PAR2 agonist, and ERK1/2 activation was suggested as the signaling pathway in fibroblasts [17]. Interestingly, other PAR, such as PAR-4 may instead be involved in mast cell migration [54]. These findings provide a strong indication of mast cell/tryptase/ PAR2/fibroblast connection influencing the migration of fibroblasts and may also influence differentiation into myofibroblasts. Previous studies have indicated that fibroblasts from IPF lungs exhibit increased PAR2 expression [19]. High numbers of $\alpha$-smooth muscle actin (SMA)-expressing myofibroblasts have been observed in IPF and asthma $[17,55]$ and increased PAR2 activation resulted in increased $\alpha$-SMA expression [18]. Altogether, these findings support our hypothesis that the mechanism behind the fibroblast migration may occur through the mast cell mediator tryptase and PAR2 activation on fibroblasts.

\section{Conclusions}

In this study, we demonstrated for the first time that human mast cells, the mast cell mediator tryptase and conditioned medium from mast cells enhance the migration capacity of human lung fibroblasts. The promigratory effect of mast cells and mast cell tryptase alone could be inhibited by a PAR2 antagonist, suggesting that these effects are mediated through PAR2 activation. Further studies are warranted to clarify the mechanisms behind these actions that may have a critical role in remodeling processes in the lung.

\section{Additional file}

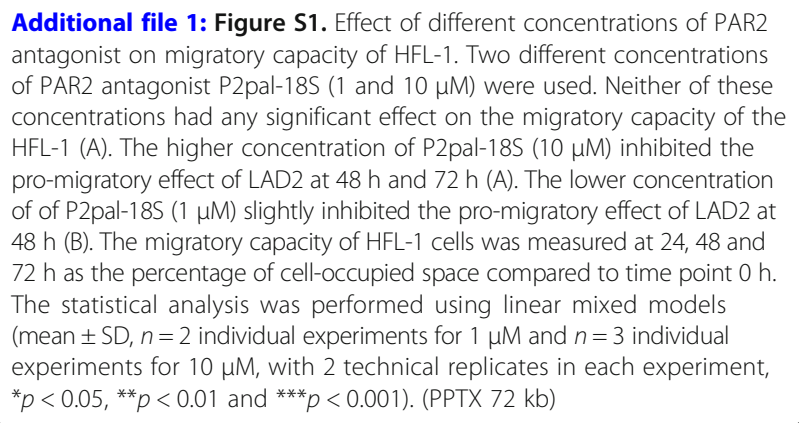

\section{Abbreviations}

aSMA: a-smooth muscle actin; BSA: Bovine serum albumin; CCL2: Chemokine (C-C motif) ligand 2; CDNA: Complementary Deoxyribonucleic acid; CM: Conditioned medium; COPD: Chronic obstructive pulmonary disease; DMEM: Dulbecco's modified eagle medium; ECM: Extracellular matrix; ELISA: Enzyme-linked immunosorbent assay; ERK1/2: Extracellular signalregulated kinases 1/2; FCIII: Fetal clone serum 3; HFL-1: Human fetal lung fibroblasts; IgE: Immunoglobulin E; IL-3: Interleukin 3; IL-6: Interleukin 6; IPF: Idiopathic pulmonary fibrosis; PAR2: Protease activated receptor 2; PBdMC: Human peripheral blood derived mast cells; PBS: Phosphate-Buffered Saline; PCR: Polymerase chain reaction; PEST: Penicillin-Streptomycin; PMD: Piecemeal degranulation; SCF: Stem cell factor; SEM: Scanning electron microscopy; TBS: Tris buffered saline; TEM: Transmission electron microscopy

\section{Acknowledgements}

We are grateful to Dr. Arnold Kirshenbaum (Laboratory of Allergic Diseases, NIAID, NIH) for kindly providing the LAD2 mast cell line. We would like to thank Bettina Margrethe Jensen for providing us protocols and experience of working with PBdMC and LAD2 cells; Annika Nybom, Lena Thiman and Marie Wildt for expert technical assistance; Catharina Müller for kindly sharing her expertise in histology; Prof. Anders Malmström for critical reading and scientific discussions. Lund University Bioimaging Center (LBIC), Lund University, is gratefully acknowledged for providing experimental resources. Unit for medical statistics and epidemiology, Skåne University hospital, is gratefully acknowledged for consulting regarding the statistical methods.

\section{Funding}

This work was financially supported by The Swedish Research Council in Medicine and Health (Grant number: 11550), the Swedish Heart-Lung Foundation, the Royal Physiographical Society in Lund, the Medical Faculty of Lund University, the Evy and Gunnar Sandberg Foundation, Greta and John Kock Foundation, the Alfred Österlund Foundation, the Crafoord Foundation, the Consul Thure Bergh Foundation, the Konung Gustaf V:s och Drottning Victorias Frimurare Foundation, ALF Grants Region Skåne and the Swedish Foundation for Strategic Research.

\section{Availability of data and materials}

The datasets analyzed during the current study are available from the corresponding author on reasonable request.

\section{Authors' contributions}

$M B$ conducted the experiments, analyzed the data, prepared the figures and the manuscript. $M B, A L C, O R, O H, L B$ and $G W T$ interpreted the results. $L B$, $A L C$ and GWT funded the study. All authors were involved in designing the research and revision of the manuscript. All authors read and approved the final version.

\section{Ethics approval and consent to participate}

All blood donors gave their written informed consent to participate in the study, which was approved by the regional ethics committee in Lund (KIT 2010-29).

Consent for publication

Not applicable. 


\section{Competing interests}

The authors declare that they have no competing interests.

\section{Publisher's Note}

Springer Nature remains neutral with regard to jurisdictional claims in published maps and institutional affiliations.

\section{Received: 5 June 2018 Accepted: 27 August 2018} Published online: 15 September 2018

\section{References}

1. Theoharides TC, Alysandratos KD, Angelidou A, Delivanis DA, Sismanopoulos N, Zhang B, Asadi S, Vasiadi M, Weng Z, Miniati A, Kalogeromitros D. Mast cells and inflammation. Biochim Biophys Acta. 2012;1822:21-33.

2. Mortaz E, Folkerts G, Redegeld F. Mast cells and COPD. Pulm Pharmacol Ther. 2011;24:367-72.

3. Andersson CK, Bergqvist A, Mori M, Mauad T, Bjermer L, Erjefalt JS. Mast cellassociated alveolar inflammation in patients with atopic uncontrolled asthma. J Allergy Clin Immunol. 2011;127:905-12.

4. Salazar LM, Herrera AM. Fibrotic response of tissue remodeling in COPD Lung. 2011:189:101-9.

5. Wygrecka M, Dahal BK, Kosanovic D, Petersen F, Taborski B, von Gerlach S, Didiasova M, Zakrzewicz D, Preissner KT, Schermuly RT, Markart P. Mast cells and fibroblasts work in concert to aggravate pulmonary fibrosis: role of transmembrane SCF and the PAR-2/PKC-alpha/Raf-1/p44/42 signaling pathway. Am J Pathol. 2013;182:2094-108.

6. Andersson CK, Andersson-Sjoland A, Mori M, Hallgren O, Pardo A, Eriksson L, Bjermer L, Lofdahl CG, Selman M, Westergren-Thorsson G, Erjefalt JS. Activated MCTC mast cells infiltrate diseased lung areas in cystic fibrosis and idiopathic pulmonary fibrosis. Respir Res. 2011;12:139.

7. Algermissen B, Hermes B, Feldmann-Boeddeker I, Bauer F, Henz BM. Mast cell chymase and tryptase during tissue turnover: analysis on in vitro mitogenesis of fibroblasts and keratinocytes and alterations in cutaneous scars. Exp Dermatol. 1999:8:193-8.

8. Cairns JA, Walls AF. Mast cell tryptase stimulates the synthesis of type I collagen in human lung fibroblasts. J Clin Invest. 1997;99:1313-21.

9. Garbuzenko E, Nagler A, Pickholtz D, Gillery P, Reich R, Maquart FX, LeviSchaffer F. Human mast cells stimulate fibroblast proliferation, collagen synthesis and lattice contraction: a direct role for mast cells in skin fibrosis. Clin Exp Allergy. 2002;32:237-46.

10. Westergren-Thorsson G, Larsen K, Nihlberg K, Andersson-Sjoland A, Hallgren $\mathrm{O}$, Marko-Varga G, Bjermer L. Pathological airway remodelling in inflammation. Clin Respir J. 2010:4(Suppl 1):1-8.

11. Gailit J, Marchese MJ, Kew RR, Gruber BL. The differentiation and function of myofibroblasts is regulated by mast cell mediators. J Invest Dermatol. 2001; 117:1113-9.

12. Ruoss SJ, Hartmann T, Caughey GH. Mast cell tryptase is a mitogen for cultured fibroblasts. J Clin Invest. 1991;88:493-9.

13. Gruber BL, Kew RR, Jelaska A, Marchese MJ, Garlick J, Ren S, Schwartz LB, Korn JH. Human mast cells activate fibroblasts: tryptase is a fibrogenic factor stimulating collagen messenger ribonucleic acid synthesis and fibroblast chemotaxis. J Immunol. 1997;158:2310-7.

14. Cairns JA. Mast cell tryptase and its role in tissue remodelling. Clin Exp Allergy. 1998;28:1460-3.

15. Lin C, von der Thusen J, Daalhuisen J, ten Brink M, Crestani B, van der Poll T, Borensztajn K, Spek CA. Pharmacological targeting of protease-activated receptor 2 affords protection from bleomycin-induced pulmonary fibrosis. Mol Med. 2015;21:576-83.

16. Soh UJ, Dores MR, Chen B, Trejo J. Signal transduction by protease-activated receptors. Br J Pharmacol. 2010;160:191-203.

17. Lin C, von der Thusen J, Daalhuisen J, ten Brink M, Crestani B, van der Poll T, Borensztajn K, Spek CA. Protease-activated receptor (PAR)-2 is required for PAR-1 signalling in pulmonary fibrosis. J Cell Mol Med. 2015;19:1346-56.

18. Borensztajn $K$, Bresser $P$, van der Loos $C$, Bot I, van den Blink B, den Bakker MA, Daalhuisen J, Groot AP, Peppelenbosch MP, von der Thusen $\mathrm{JH}$, Spek CA. Protease-activated receptor-2 induces myofibroblast differentiation and tissue factor up-regulation during bleomycin-induced lung injury: potential role in pulmonary fibrosis. Am J Pathol. 2010;177: 2753-64.
19. Wygrecka M, Kwapiszewska G, Jablonska E, von Gerlach S, Henneke I, Zakrzewicz D, Guenther A, Preissner KT, Markart P. Role of proteaseactivated receptor-2 in idiopathic pulmonary fibrosis. Am J Respir Crit Care Med. 2011;183:1703-14.

20. Palmer HS, Kelso EB, Lockhart JC, Sommerhoff CP, Plevin R, Goh FG, Ferrell WR. Protease-activated receptor 2 mediates the proinflammatory effects of synovial mast cells. Arthritis Rheum. 2007;56:3532-40.

21. Kleiveland CR. Peripheral blood mononuclear cells. In: Verhoeckx K, Cotter P Lopez-Exposito I, Kleiveland C, Lea T, Mackie A, Requena T, Swiatecka D, Wichers $\mathrm{H}$, editors. The Impact of Food Bioactives on Health: in vitro and ex vivo models, vol. 2015. Cham (CH): Springer Copyright; 2015. p. 161-7.

22. Wang XS, Sam SW, Yip KH, Lau HY. Functional characterization of human mast cells cultured from adult peripheral blood. Int Immunopharmacol. 2006;6:839-47.

23. Andersen HB, Holm M, Hetland TE, Dahl C, Junker S, Schiotz PO, Hoffmann $\mathrm{HJ}$. Comparison of short term in vitro cultured human mast cells from different progenitors - peripheral blood-derived progenitors generate highly mature and functional mast cells. J Immunol Methods. 2008;336:166-74.

24. Radinger M, Jensen BM, Kuehn HS, Kirshenbaum A, Gilfillan AM. Generation, isolation, and maintenance of human mast cells and mast cell lines derived from peripheral blood or cord blood. Curr Protoc Immunol. 2010;7:37.

25. Saito $H$. Culture of human mast cells from hemopoietic progenitors. Methods Mol Biol. 2006:315:113-22.

26. Laidlaw TM, Steinke JW, Tinana AM, Feng C, Xing W, Lam BK, Paruchuri S, Boyce JA, Borish L. Characterization of a novel human mast cell line that responds to stem cell factor and expresses functional FcepsilonRI. J Allergy Clin Immunol. 2011;127:815-22.

27. Guhl S, Babina M, Neou A, Zuberbier T, Artuc M. Mast cell lines HMC-1 and LAD2 in comparison with mature human skin mast cells--drastically reduced levels of tryptase and chymase in mast cell lines. Exp Dermatol. 2010;19:845-7.

28. Oehmcke $\mathrm{S}$, Morgelin M, Herwald $\mathrm{H}$. Activation of the human contact system on neutrophil extracellular traps. J Innate Immun. 2009;1:225-30.

29. Kuehn HS, Radinger M, Gilfillan AM. Measuring mast cell mediator release. Curr Protoc Immunol. 2010;91:7-38.

30. Radinger M, Jensen BM, Swindle E, Gilfillan AM. Assay of mast cell mediators. Methods Mol Biol. 2015:1220:307-23.

31. Westergren-Thorsson G, Onnervik PO, Fransson LA, Malmstrom A. Proliferation of cultured fibroblasts is inhibited by L-iduronate-containing glycosaminoglycans. J Cell Physiol. 1991;147:523-30.

32. Larsson-Callerfelt AK, Hallgren $O$, Andersson-Sjoland A, Thiman L, Bjorklund J, Kron J, Nihlberg K, Bjermer L, Lofdahl CG, Westergren-Thorsson G. Defective alterations in the collagen network to prostacyclin in COPD lung fibroblasts. Respir Res. 2013;14:21.

33. Thelin MA, Svensson KJ, Shi X, Bagher M, Axelsson J, Isinger-Ekstrand A, van Kuppevelt TH, Johansson J, Nilbert M, Zaia J, et al. Dermatan sulfate is involved in the tumorigenic properties of esophagus squamous cell carcinoma. Cancer Res. 2012:72:1943-52.

34. Westergren-Thorsson G, Bagher M, Andersson-Sjoland A, Thiman L, Lofdahl CG, Hallgren O, Bjermer L, Larsson-Callerfelt AK. VEGF synthesis is induced by prostacyclin and TGF-beta in distal lung fibroblasts from COPD patients and control subjects: implications for pulmonary vascular remodelling. Respirology. 2018;23:68-75

35. Geback T, Schulz MM, Koumoutsakos P, Detmar M. TScratch: a novel and simple software tool for automated analysis of monolayer wound healing assays. Biotechniques. 2009:46:265-74.

36. Jensen BM, Frandsen PM, Raaby EM, Schiotz PO, Skov PS, Poulsen LK. Molecular and stimulus-response profiles illustrate heterogeneity between peripheral and cord blood-derived human mast cells. J Leukoc Biol. 2014;95:893-901.

37. Payne V, Kam PC. Mast cell tryptase: a review of its physiology and clinical significance. Anaesthesia. 2004;59:695-703.

38. Pejler G, Ronnberg E, Waern I, Wernersson S. Mast cell proteases: multifaceted regulators of inflammatory disease. Blood. 2010;115:4981-90.

39. Klion AD, Noel P, Akin C, Law MA, Gilliland DG, Cools J, Metcalfe DD, Nutman TB. Elevated serum tryptase levels identify a subset of patients with a myeloproliferative variant of idiopathic hypereosinophilic syndrome associated with tissue fibrosis, poor prognosis, and imatinib responsiveness. Blood. 2003;101:4660-6.

40. Siiskonen H, Poukka M, Bykachev A, Tyynela-Korhonen K, Sironen R, Pasonen-Seppanen S, Harvima IT. Low numbers of tryptase+ and chymase+ mast cells associated with reduced survival and advanced tumor stage in melanoma. Melanoma Res. 2015;25:479-85. 
41. Frungieri MB, Weidinger S, Meineke V, Kohn FM, Mayerhofer A. Proliferative action of mast-cell tryptase is mediated by PAR2, COX2, prostaglandins, and PPARgamma : possible relevance to human fibrotic disorders. Proc Natl Acad Sci U S A. 2002:99:15072-7.

42. Blank U, Rivera J. The ins and outs of IgE-dependent mast-cell exocytosis. Trends Immunol. 2004;25:266-73.

43. Crivellato E, Nico B, Gallo VP, Ribatti D. Cell secretion mediated by granuleassociated vesicle transport: a glimpse at evolution. Anat Rec. 2010;293: 1115-24.

44. Dvorak AM, Kissell S. Granule changes of human skin mast cells characteristic of piecemeal degranulation and associated with recovery during wound healing in situ. J Leukoc Biol. 1991;49:197-210.

45. Rothe MJ, Kerdel FA. The mast cell in fibrosis. Int J Dermatol. 1991;30:13-6.

46. Moon TC, Befus AD, Kulka M. Mast cell mediators: their differential release and the secretory pathways involved. Front Immunol. 2014:5:569.

47. Dolgachev VA, Ullenbruch MR, Lukacs NW, Phan SH. Role of stem cell factor and bone marrow-derived fibroblasts in airway remodeling. Am J Pathol. 2009;174:390-400

48. Jensen BM, Metcalfe DD, Gilfillan AM. Targeting kit activation: a potential therapeutic approach in the treatment of allergic inflammation. Inflamm Allergy Drug Targets. 2006;6:57-62.

49. Ito T. Stem cell factor programs the mast cell activation phenotype. J Immunol. 2012;188:5428-37.

50. Hogaboam C, Kunkel SL, Strieter RM, Taub DD, Lincoln P, Standiford TJ, Lukacs NW. Novel role of transmembrane SCF for mast cell activation and eotaxin production in mast cell-fibroblast interactions. J Immunol. 1998;160: 6166-71.

51. Kondo S, Kagami S, Kido H, Strutz F, Muller GA, Kuroda Y. Role of mast cell tryptase in renal interstitial fibrosis. J Am Soc Nephrol. 2001;12:1668-76.

52. Crivellato E, Nico B, Mallardi F, Beltrami CA, Ribatti D. Piecemeal degranulation as a general secretory mechanism? Anat Rec A Discov Mol Cell Evol Biol. 2003;274:778-84.

53. Sevigny LM, Zhang P, Bohm A, Lazarides K, Perides G, Covic L, Kuliopulos A. Interdicting protease-activated receptor-2-driven inflammation with cellpenetrating pepducins. Proc Natl Acad Sci U S A. 2011;108:8491-6.

54. Lin YP, Nelson C, Kramer H, Parekh AB. The Allergen Der $\mathrm{p3}$ from House Dust Mite Stimulates Store-Operated Ca (2+) Channels and Mast Cell Migration through PAR4 Receptors. Mol Cell. 2018;70:228-41.

55. Brewster CE, Howarth PH, Djukanovic R, Wilson J, Holgate ST, Roche WR. Myofibroblasts and subepithelial fibrosis in bronchial asthma. Am J Respir Cell Mol Biol. 1990;3:507-11.

Ready to submit your research? Choose BMC and benefit from:

- fast, convenient online submission

- thorough peer review by experienced researchers in your field

- rapid publication on acceptance

- support for research data, including large and complex data types

- gold Open Access which fosters wider collaboration and increased citations

- maximum visibility for your research: over $100 \mathrm{M}$ website views per year

At $\mathrm{BMC}$, research is always in progress.

Learn more biomedcentral.com/submissions 